\title{
Erratum: Elephant population responses to increased density in Kruger National Park
}

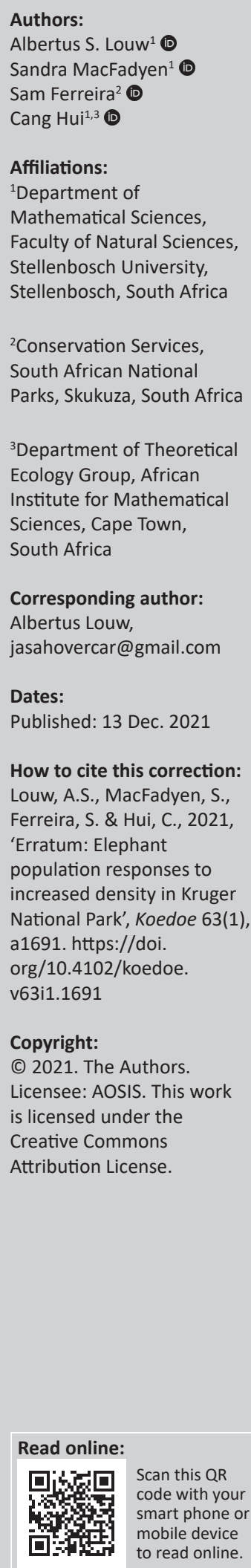

In the published article, Louw, A.S., MacFadyen, S., Ferreira, S. \& Hui, C., 2021, 'Elephant population responses to increased density in Kruger National Park', Koedoe 63(1), a1660. https:/ / doi.org/10.4102/koedoe.v63i1.1660, there was a mistake in the legend for Figure $1 \mathrm{~b}$ as published. The colour labels of the legend in Figure $1 \mathrm{~b}$ was replaced with text from the legend of Figure 1a by mistake.

The original incorrect legend for Figure 1b:

\begin{tabular}{|l|}
\hline Main camps \\
Main rivers \\
Kruger national park \\
Elephant density $\left(\mathrm{n} / \mathrm{km}^{2}\right)$ \\
long-term density mean \\
$\square \quad 26-38$ \\
$\square \quad 39-40$ \\
$\square \quad 41-42$ \\
\hline
\end{tabular}

The revised and updated legend for Figure 1b:

\begin{tabular}{|l|}
\hline Main Camps \\
Main Rivers \\
Kruger National Park \\
Elephant density $\left(\mathrm{n} / \mathrm{km}^{2}\right)$ \\
long-term density mean \\
$0.0-0.5(60 \%)$ \\
$0.6-1.0(31 \%)$ \\
$1.1-2.9(9 \%)$ \\
\hline
\end{tabular}

The publisher apologise for this error. The correction does not change the study's findings of significance or overall interpretation of the study's results or the scientific conclusions of the article in any way. 


\section{Elephant population responses to increased density in Kruger National Park}

\begin{tabular}{|c|c|}
\hline \multicolumn{2}{|c|}{$\begin{array}{l}\text { Authors: } \\
\text { Albertus S. Louw }^{1} \\
\text { Sandra MacFadyen } \\
\text { Sam Ferreira } \\
\text { Cang Hui } \\
\text { Ca }\end{array}$} \\
\hline \multicolumn{2}{|c|}{$\begin{array}{l}\text { Affiliations: } \\
{ }^{1} \text { Department of } \\
\text { Mathematical Sciences, } \\
\text { Faculty of Natural Sciences, } \\
\text { Stellenbosch University, } \\
\text { Stellenbosch, South Africa }\end{array}$} \\
\hline \multicolumn{2}{|c|}{$\begin{array}{l}{ }^{2} \text { Conservation Services, } \\
\text { South African National Parks, } \\
\text { Skukuza, South Africa }\end{array}$} \\
\hline \multicolumn{2}{|c|}{$\begin{array}{l}{ }^{3} \text { Department of Theoretical } \\
\text { Ecology Group, African } \\
\text { Institute for Mathematical } \\
\text { Sciences, Cape Town, } \\
\text { South Africa }\end{array}$} \\
\hline \multicolumn{2}{|c|}{$\begin{array}{l}\text { Corresponding author: } \\
\text { Albertus Louw, } \\
\text { jasahovercar@gmail.com }\end{array}$} \\
\hline \multicolumn{2}{|c|}{$\begin{array}{l}\text { Dates: } \\
\text { Received: } 17 \text { Oct. } 2020 \\
\text { Accepted: } 23 \text { Mar. } 2021 \\
\text { Published: } 10 \text { June } 2021\end{array}$} \\
\hline \multicolumn{2}{|c|}{$\begin{array}{l}\text { How to cite this article: } \\
\text { Louw, A.S., MacFadyen, S., } \\
\text { Ferreira, S. \& Hui, C., 2021, } \\
\text { 'Elephant population } \\
\text { responses to increased } \\
\text { density in Kruger National } \\
\text { Park', Koedoe 63(1), a1660. } \\
\text { https://doi.org/10.4102/ } \\
\text { koedoe.v63i1.1660 }\end{array}$} \\
\hline \multicolumn{2}{|c|}{$\begin{array}{l}\text { Copyright: } \\
\text { (C) } 2021 \text {. The Authors. } \\
\text { Licensee: AOSIS. This wor } \\
\text { is licensed under the } \\
\text { Creative Commons } \\
\text { Attribution License. }\end{array}$} \\
\hline \multicolumn{2}{|l|}{ Read online: } \\
\hline 口ipg & $\begin{array}{l}\text { Scan this QR } \\
\text { code with your } \\
\text { smart phone or } \\
\text { mobile device } \\
\text { to read online. }\end{array}$ \\
\hline
\end{tabular}

The elephant population in the Kruger National Park (KNP) has been increasing since the cessation of culling in the mid-1990s. This contrasts with recent trends in elephant populations in many parts of Africa where poaching continues to decrease numbers. Logistic growth theory predicts that increased competition for vital resources when densities increase should serve to constrain population growth, implying a negative density-growth correlation. We tested this prediction using 28 years of elephant census data to investigate how the growth of the KNP's elephant population responds to increasing elephant density from the period 1985 to 2012. We expected a spatially variable population growth pattern in response to the distribution of elephant densities in the park and thus classified the park into zones with low, medium or high long-term (28 years) average, dry-season elephant density. Zones were named 'peripheral', 'semi-peripheral' and 'core' zones, respectively, and represent proxies of resource availability to elephant herds. Using a Stochastic Ricker growth model, we tested for the presence of negative density-dependence in population growth in the core versus peripheral zones. In response, we only detected density-dependent growth in the core zone. Overall the population grew at $4.1 \%$ per year, coupled with local recruitment rates that increased over time, particularly in the peripheral zones. These density-dependent trends support previous observations of homogenisation of elephant distribution and density across the KNP landscapes.

Conservation implications: Density-dependent changes to elephant growth rates are scaledependent (local vs. park level). Only core areas with long-term high density show signs of density-dependent growth. Overall, the distributions of elephants are homogenising in the KNP. Conservation authorities should monitor the impact of such homogenisation to landscape heterogeneity. The spatial variation of the negative density-growth correlation, especially between the core and peripheral zones, can be considered when developing effective strategies to manage the KNP elephant population.

Keywords: African elephants Loxodonta africana; population growth; density dependence; spatial distributions; conservation management.

\section{Introduction}

Despite threats of poaching and habitat loss, trends in the numbers of African elephants (Loxodonta africana) in southern Africa contrast with their declining numbers in the rest of the continent (Chase et al. 2016). South Africa epitomises these trends with populations increasing in trans-frontier (Selier et al. 2016) and fence protected areas (Pretorius, Garaï \& Bates 2019). Apart from being a key component of South Africa's natural heritage, elephants are ecological engineers or habitat modifiers because of the substantial influence they exert on the habitats they share with other co-occurring species (Valeix et al. 2011). That is, elephants can change the structure of vegetation whilst browsing and can therefore become a catalyst for landscape state change (Eckhardt, Van Wilgen \& Biggs 2000; Trollope et al. 1998). As a result, the influence of elephants on ecosystems has stimulated much debate (Van Aarde, Whyte \& Pimm 1999; Van Wyk \& Fairall 1969).

The Kruger National Park (KNP) in South Africa is a large, protected area where elephant numbers increased from an estimated 10 animals in the early 1900s to over 17000 elephants in 2015 (Ferreira, Greaver \& Simms 2017). Historically, authorities linked increasing elephant population size to vegetation impact, resulting in action being taken to control elephant numbers through culling (Van Aarde, Whyte \& Pimm 1999). Changes in conservation philosophy led to the subsequent cessation of elephant culling in 1995, in favour of allowing density-dependent processes to guide population dynamics over the longer term (Whyte et al. 1999). In the same period (1997), the systematic removal of many artificial water points in the park was implemented to regulate game distributions by returning surface water availability to a more natural state (Pienaar et al. 1997). 
The authorities also increased efforts to provide more land for elephants by removing fences from neighbouring private protected areas and international trans-frontier parks since 1996 (Venter et al. 2008). In general, these management actions aim to let the spatial heterogeneity of resources, such as water and vegetation, drive elephant distributions and regulate the impacts elephants exerted on landscape heterogeneity in lieu of directly regulating population size (Owen-Smith et al. 2006; Van Aarde et al. 1999).

To date, the effectiveness of changing elephant management strategies to achieve different biodiversity conservation goals remains open to debate. Elephant distribution in the KNP has become less clumped and more homogeneous as their density has increased (MacFadyen et al.2019). This is likely because of elephants' responses to local resource and space constraints from crowding and consequent movement into relatively lower quality habitats (MacFadyen et al. 2019; Robson \& Van Aarde 2018) or could be a result of artificial water holes still enabling elephants to utilise areas far from natural water sources (Purdon \& Van Aarde 2017). Many have argued that this movement into lower quality habitats should result in decreased survival and birth rates and eventually serve to regulate population growth dynamics (Owen-Smith et al. 2006; Robson \& Van Aarde 2018). Others have speculated that this has already contributed to lower population growth rates as new management interventions were introduced (Ferreira et al. 2017). Increased elephant density and the spatial variation of climate and vegetation in the park are expected to jointly affect elephant population growth (Robson 2015). On the other hand, as elephants spread further into the landscape, they will also utilise and potentially disturb a much larger part of the vegetation in the park (MacFadyen et al. 2019; Young, Ferreira \& Van Aarde 2009a). This will compromise and even counter management goals of letting landscape heterogeneity drive and regulate the distribution of elephants.

Population change rate is dependent on population density, whilst the strength of density-growth correlation should vary across landscapes (Owen-Smith et al. 2006). Large vertebrates typically display convex curves of density-dependent population growth patterns (Sibly et al. 2005). This means that density-dependent growth only becomes evident once the population is close to the carrying capacity of the habitat (Fowler 1981), as is often seen in smaller, fenced reserves. Such density dependence originates from the way large vertebrates respond to aggravating resource constraints. For example, when density increases juvenile survival rates typically decrease followed by reduced reproductive outputs, whilst adult survival rates decrease, culminating in reduced population growth (Eberhardt 2002).

Like most large herbivores, elephants choose landscapes based on water, food, comfort and safety (Boult et al. 2019; Chamaillé-Jammes, Valeix \& Fritz 2007; Kinahan, Pimm \& Van Aarde 2007; Purdon \& Van Aarde 2017; Wittemyer et al. 2017) and make large seasonal movements (e.g. Cook,
Henley \& Parrini 2015). During the dry season, the distribution of water is a primary driver of elephant space use (Chamaillé-Jammes et al. 2007; Purdon \& Van Aarde 2017). This need for water often exceeds the selection of food resources in water-scarce ecosystems and thus elephants are restricted to habitats near water sources. As elephant breeding herds normally use the same dry season home ranges from year to year (Young, Ferreira \& Van Aarde 2009b), we assume the dry season is the key period during which density-dependent processes will activate. As negative density-dependent growth only occurs in areas with high elephant density, we might not be able to detect it at a parkwide scale. As a result, we focus on how local population growth varies spatially in different long-term density zones throughout the park.

Negative density-dependence refers to the decline in population growth rate in response to increasing population size or density (Hixon \& Johnson 2009), which is typically associated with the effect of intense resource competition from overcrowding. To identify the effects of densitydependent growth, we consider two lines of evidence. Firstly, we present a statistical test for negative densitydependent growth described by Dennis and Taper (1994) that incorporates logistic growth theory (Tsoularis \& Wallace 2002; Verhulst 1845). This approach differs from earlier works that identify changes to growth trends by comparing goodness-of-fit of growth models over different time periods (Ferreira et al. 2017) or identify factors influencing population growth with regression models (Robson 2015). Secondly, we quantify trends in the recruitment rates of elephant calves. Mainstream large vertebrate models often predict juvenile survival as the first demographic variable to respond to resource constraints (Eberhardt 2002; Trimble, Ferreira \& Van Aarde 2009). The calves counted during the annual dry season censuses, represent those born and also survived between the previous and present dry season. This recruitment serves as a proxy to evaluate early demographic responses to population density (Eberhardt 2002; Trimble et al. 2009). Here we expect a negative density-dependent recruitment rate from density increases and the resulting resource constraints in the dry season.

\section{Research methods and design Study area}

The KNP is situated in the north-eastern part of South Africa, bordered by Mozambique and Zimbabwe to the east and north, respectively (Figure 1a). It covers an area of approximately 2 million hectares and is comprised of 35 predominantly savanna and woodland ecosystems (Gertenbach 1983) including a number of artificial water points at scattered locations, permanent and seasonal rivers pass through the park and water supply network. The KNP has a summer rainfall season (Gertenbach 1983), with the south-western part receiving higher annual rainfall (Figure 1a; MacFadyen et al. 2018). 


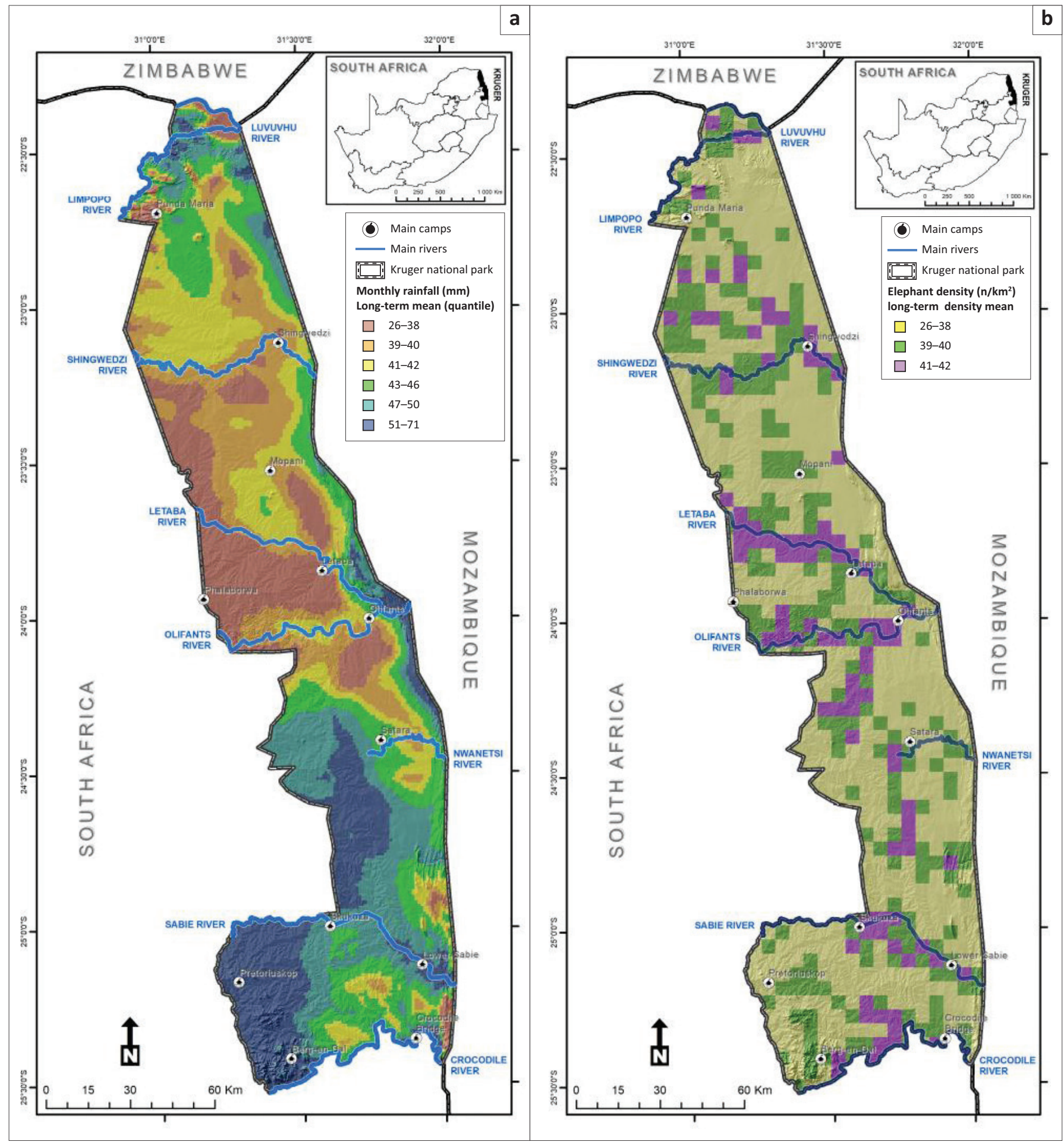

FIGURE 1: (a) The Kruger National Park, South Africa, lies between latitudes $22^{\circ} 19^{\prime} 40^{\prime \prime} \mathrm{S}$ to $25^{\circ} 31^{\prime} 44^{\prime \prime} \mathrm{S}$ and longitudes $30^{\circ} 53^{\prime} 18^{\prime \prime} \mathrm{E}$ to $32^{\circ} 01^{\prime} 59^{\prime \prime} \mathrm{E}$. Main rivers (in blue) supply water throughout the year. Rainfall occurs mainly in summer and varies in the park. The long-term average monthly rainfall for areas is indicated in the figure by a colour sequence from red (dry) to blue (wet). (b) Average elephant density observed in each $25 \mathrm{~km}^{2}$ grid-cell throughout the study period (1985-2012). Grid-cell colour indicates density of elephants per square kilometre. High density cells are coloured in purple, whilst medium and low-density cells are in green and yellow. The data are from yearly elephant censuses.

\section{Data collection}

For this study, we used census data from annual aerial counts conducted in the KNP between 1985 and 2012. All censuses were flown during the dry season (July / August/September), when reduced foliage makes elephant spotting easier (Van Aarde et al. 1999). Counts were conducted using a spotting crew and helicopter that systematically flew over 21 designated census blocks to record all elephants sighted. Each observed herd is recorded with the geolocation, number of elephants in the herd and group type (i.e. bull group or herd group). Bull groups consist of only bull animals whilst herd groups are a mix of cows and bulls of different age classes. In these mixed groups, the number of calves younger than 1 year was also recorded. No information was recorded on elephant deaths, immigrations or emigrations, which 
may result in an underestimate of birth rates. These data only represent a winter account of elephant distributions. However, water availability and foraging range are limited to a larger degree in these drier winter months (Codron et al. 2006; MacFadyen et al.2019; Thomas, Holland \& Minot 2008), and it is still the best representation of long-term elephant population distributions in the KNP. See Whyte (2001) for a full description of the census methodology.

\section{Data preparation}

All statistical analyses were carried out using $\mathrm{R}$ version 3.6.1 ( $\mathrm{R}$ Core Team 2019) and associated $\mathrm{R}$ packages referenced in the text. Firstly, we divided the KNP into a grid with 3738 cells of $5 \mathrm{~km} \times 5 \mathrm{~km}$ and aggregated the total number of elephants observed in each grid cell for each census year, distinguishing elephants in bull groups, elephants in mixed herd groups and number of calves present. We then calculated: (1) the density of elephants per square kilometre in each grid cell for each year (Equation 1) and (2) the proportion of calves per herd born since the previous census using raster (Hijmans 2020). We defined local population density as follows:

$d_{i}(t)=\frac{\sum_{j} n_{i j}(t)}{A_{i}}$

[Eqn 1]

where $d_{i}(t)$ is the density in the $i$-th grid cell at year $t ; A_{i}$ the surface area of the $i$-th grid cell $\left(25 \mathrm{~km}^{2}\right)$; and $n_{i j}(t)$ the total number of elephants in the $j$-th point observation of an elephant group in grid cell $i$ in year $t$.

We then determined the long-term average density of elephants for each grid cell in the KNP from 1985 to 2012. That is, for each cell we estimated the average density from annual census records; for cell $i$, it is the average of $d_{i}(t)$ over $t$. Grid cells were then assigned into three zones according to this long-term average density pattern: periphery (0.0-0.5), semi-periphery (0.5-1.0) and core zone (>1) (units are elephants per square kilometre). We then summarised the growth patterns in grid cells for each zone and produced a map that illustrates the three zones. Throughout our investigation, we made the distinction between time periods when the population was constrained by culling (1985-1995) and when culling was stopped (1996-2012). We did this because culling aimed to maintain the KNP's elephant population at a roughly constant size and would thus have obstructed normal population growth rates.

\section{Growth rates}

To estimate the overall growth trends of elephant population numbers, we fitted an exponential growth model to the average, park-wide elephant density from 1985 to 2012 using the least-squares method. We fitted separate exponential models for the two periods: (1) when the population was maintained by culling (1985-1995) and (2) when the population was released from culling (1996-2012): $d(t)=d_{0} e^{r t}$

where $d(t)$ is the total elephant population density at time $t$; $d_{0}$ the initial population density; and $r$ the per-capita annual growth rate.

To identify the effect of elephant population size on growth rate, we used a statistical test for density-dependent growth described by Dennis and Taper (1994). We applied this test first to the time-series of park-wide total population size and then to the time-series of total population size in each of the three zones (core, semi-periphery and periphery). This test assumes growth happens according to a stochastic Ricker model, that is, a discrete-time model of logistic population growth, described as follows:

$N_{t+1}=N_{t} \exp \left(a+b N_{t}+\sigma N_{t}\right)$,

[Eqn 3]

where $N_{t}$ is population size at time $t ; a$ and $b$ are growth rate parameters describing the density-independent and density-dependent components of growth, respectively and $Z_{t}$ is a noise component reflecting added stochasticity in the model. Therefore, if $b<0$, this indicates a negative densitydependent growth in the population dynamics, suggesting a decline in growth rate in response to the increase of population density (Hixon \& Johnson 2009). We tested whether $b$ is significantly less than zero by assessing whether a model assuming $b<0$ fits the observed population growth significantly better than the null model assuming $b=0$. We conducted the test separately for the period when the population size was maintained through culling (1985-1995) and the period when the population had no culling (1996-2012).

To assess how well growth models described the observed population growth, we compared our estimated model to observed time-series data. To further uncover any potential patterns in the population growth of different zones, we fitted a smooth line to the time series using a smoothed conditional mean function in ggplot2 (Wickham 2016).

\section{Recruitment rates}

For each observed mixed herd, the number of calves that were born and survived since the previous census year was documented. In this context, we quantified recruitment rate as the ratio of calves to other animals in each group. The subsequent metric represents how productive or fertile cows in each elephant herd and specific grid cell were, as well as how well calves from the previous year survived for a specific year. However, it is worth noting that the calf survival might have been overestimated because of the fact that the census was conducted during the dry season when resources are limited, so some calves could still succumb to resources limitations after the census. We specifically do not refer to birth rate, because we have no data on actual calf births or deaths. To estimate yearly recruitment rate, we calculated the proportion of the herd 
made up of calves and reported the average for herds in each grid cell as follows:

$$
R_{i}=\frac{\sum_{j}^{n_{i}} \frac{c_{i j}}{h_{i j}}}{n_{i}}
$$

where $R_{i}$ is the average recruitment rate per herd group in the $i$-th cell, $c_{i j}$ the number of calves in the $j$-th elephant herd in cell $i$, and $h_{i j}$ the number of elephants in the rest of the herd. The number of herd-groups in a grid cell is $n_{i}$. In this calculation, we excluded bull groups as calves are present only in mixed herds. To check whether recruitment rates differed significantly between grid cells belonging to the three different zones, we used the non-parametric MannWhitney $U$ test. This statistical test is robust for data that is not normally distributed, for example, our data had unequal number of cells in the different zones. Furthermore, to reduce skewness in the distribution of recruitment rates, we transformed the recruitment rate by its cube root. We then fitted a smoothed conditional mean to the time series (Wickham 2016) to display recruitment rate trends in the core, semi-peripheral and peripheral zones. A non-parametric Mann-Kendall test was then conducted to test for the presence of a significant trend in elephant recruitment over the study period (between 1985 and 2012). We used this test because elephant recruitment rate was not normally distributed according to a Shapiro-Wilk test.

\section{Results}

\section{Growth and density-dependence}

During the period elephants were culled (1985-1995), the population was maintained at approximately 0.36 elephants per square kilometre (Figure 2; Appendix 1 Table 1-A1; $\left.R^{2}=0.34, \mathrm{~F}(1,9)=6.16, r=0.006, p=0.035\right)$. In the period after 1995 , growth can be described by an exponential model with per capita annual growth rate of $4.1 \%$ (Figure 2; Appendix 1 Table 1-A1; $\left.R^{2}=0.95, \mathrm{~F}(1,15)=278.4, r=0.041, p<0.001\right)$.

During the culling period (1985-1995), the overall population and the zoned populations showed significant negative density-dependent growth (Appendix 1 Table 2-A1, Appendix 1 Figure 1-A1). For the post-culling period, no negative density-dependent growth was observed in the overall population (Figure 3a). That is, $b$ was $>0$ in the stochastic Ricker growth model (Eqn 3 ) and thus we could not reject the null hypothesis $(b=0)$ (see Appendix 1 Table 2-A1). However, we did find a significant $(\alpha=0.05)$ negative densitydependent component for elephant growth in the core zone $\left(b=-1.4 \times 10^{-4}\right)$. In the semi-peripheral and peripheral zones, the bootstrap confidence intervals for the parameter $b$ included zero, indicating no density-dependent effects.

Elephant densities increased in the core zone after culling practices (red line in Figure 4a). After 2008, elephant densities in these core areas began to stabilise, whereas in the semiperipheral and peripheral zones elephant densities sharply increased even after 2008 (Figure 4a).

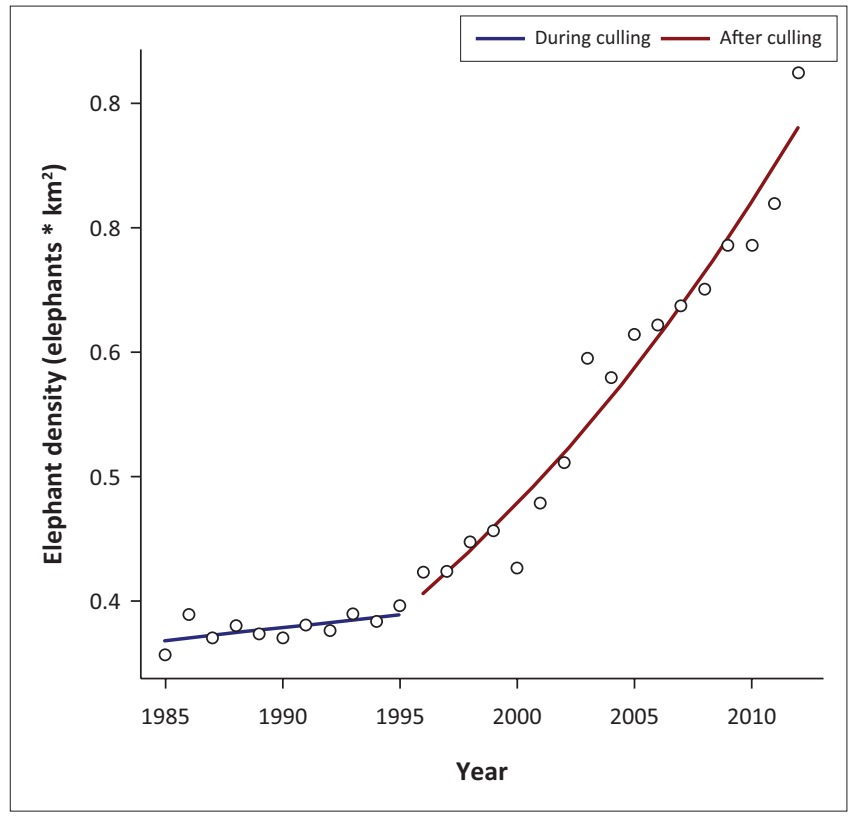

Note: Please see the article, Louw, A.S., MacFadyen, S., Ferreira, S. \& Hui, C., 2021, 'Elephant population responses to increased density in Kruger National Park', Koedoe 63(1), a1660. https://doi.org/10.4102/koedoe.v63i1.1660, for more information.

FIGURE 2:Time series of park-wide elephant density in elephants per square kilometre, as obtained from annual census (circles). Lines represent exponential growth models (Eqn 2) fitted to the census time series for the period with culling (1985-1995) in blue and without culling (1996-2012) in red.

\section{Recruitment rates}

Elephant recruitment rates in the peripheral and semiperipheral zones had a significant upward trend between 1985 and 2012 (Mann-Kendall tests for trends, $p=0.017$ and $p=0.034$, respectively; Table 4-A1). Recruitment rates in the core zone did not have a significant trend $(p=0.277)$ but were in general higher than the rates in the semi-peripheral and peripheral zones. Recruitment rates in the semi-peripheral zone were also higher than in the peripheral zone (Mann-Whitney U tests, Table 3-A1). Over time, however, the trends in recruitment appear to converge and all zones experienced similar recruitment rates by 2012 (Figure 4b).

\section{Discussion}

\section{Scale and density-dependent growth}

Elephant population growth rates in the KNP were expected to drop in response to management approaches that enhance habitat variability in the landscape (Ferreira et al. 2017). Over time, these reduced growth rates would manifest as reduced birth rates and increased mortality because of increased spatial variability of resources and thus increased competition for space and resources as population density increases (Van Aarde et al. 1999). We observed, however, that the KNP's population has been growing exponentially at an annual rate of $4.1 \%$ since culling stopped in 1995. These results are similar to those reported by Ferreira et al. (2017) but lower than the intrinsic growth rate reported during the time of culling (Whyte 2001).

African elephant populations, when left undisturbed, typically experience exponential growth (Slotow et al. 2006). With persistent poaching, however, elephant population growth 


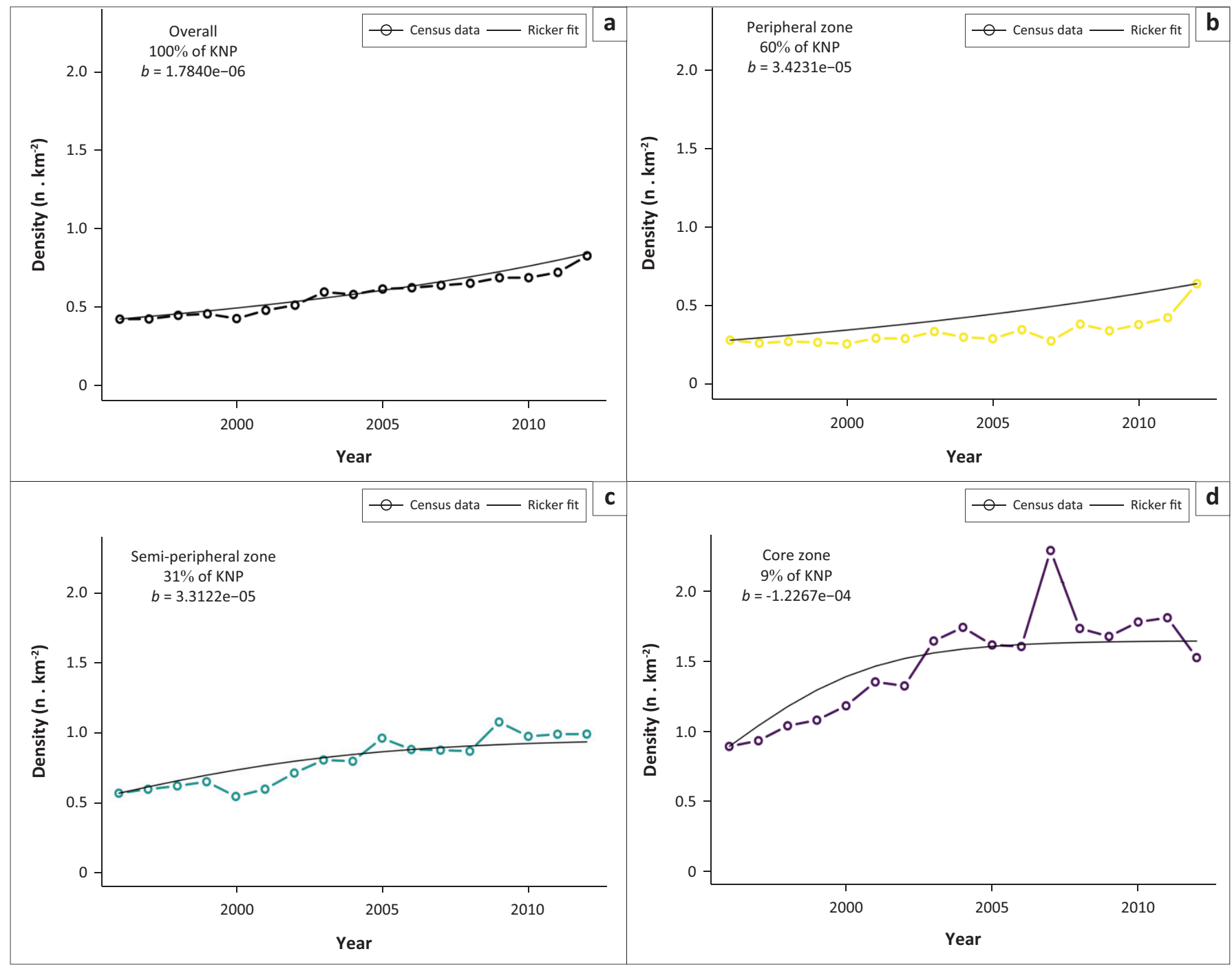

Note: Please see the article, Louw, A.S., MacFadyen, S., Ferreira, S. \& Hui, C., 2021, 'Elephant population responses to increased density in Kruger National Park', Koedoe 63(1), a1660. https://doi. org/10.4102/koedoe.v63i1.1660, for more information.

KNP, Kruger National Park.

FIGURE 3: Deterministic component of Stochastic Ricker growth models (Eqn 3) fitted to time series of elephant population in the Kruger National Park (1996-2012). Models shown for overall population (a), and separately for the three zones in the park; peripheral (b), semi-peripheral (c) and core (d). Test for negative density dependent growth reported significant for the core zone (d). Model parameter estimates in Appendix 1 (Table 2-A1).

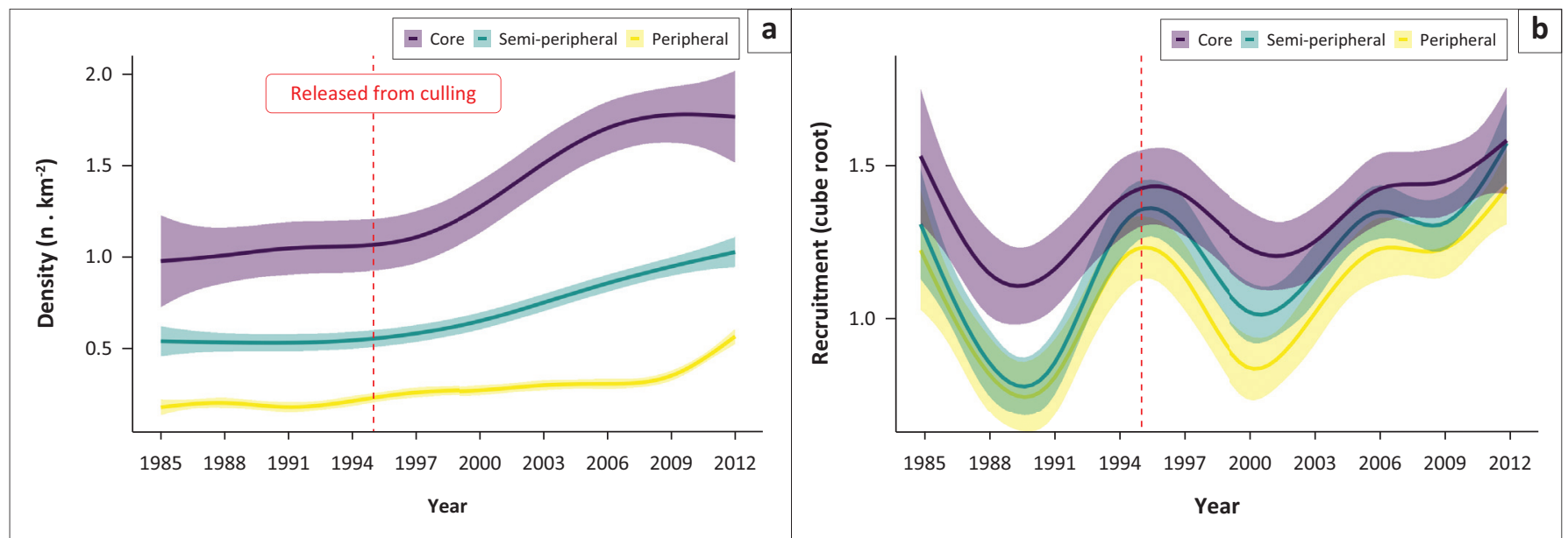

Note: Please see the article, Louw, A.S., MacFadyen, S., Ferreira, S. \& Hui, C., 2021, 'Elephant population responses to increased density in Kruger National Park', Koedoe 63(1), a1660. https://doi. org/10.4102/koedoe.v63i1.1660, for more information.

FIGURE 4: Time series of (a) elephant density per grid cell and (b) recruitment rate. The solid lines represent a smoothed conditional-means fit to the data in ggplot2. Filled regions show $95 \%$ confidence intervals. Grid cells were classified into three zones according to the average elephant density observed in them through the study period. Colour distinguishes the zones (grid cells that had a low average elephant density were classified as 'peripheral' and are shown in yellow, grid cells with medium average density were 'semi-peripheral' and are shown in blue and grid cells with high elephant density were defined as the 'core zone' for elephants and are in purple). A cube root transform is used to reduce skewness in the distribution of the recruitment rates. Recruitment rate is defined as the proportion of calves in a herd and is reported as an average for each grid cell (Eqn 4). Recruitment in the peripheral and semi-peripheral zones had significant upward trend, by Mann-Kendall test for trend (Table 4-A1). 
can be disrupted (Chase et al. 2016) to such an extent that many places across the continent now have only $25 \%$ of expected elephant numbers (Robson et al. 2017). Different management strategies can also influence natural population dynamics and can disrupt natural densitydependent processes in protected areas. For instance, no density-dependent population growth has been recorded in elephants in the Addo Elephant National Park (AENP) (Gough \& Kerley 2006) as various land acquisitions have increased the area available to elephants (Kerley, Boshoff \& Knight 2002) and thereby potentially delayed the effect of resource constraints associated with increasing densities. During the culling era in the KNP, authorities aimed to maintain the elephant population size to around 7500 animals (Van Aarde et al. 1999). In practice, to achieve this annual culling, quotas were set based on the number of elephants counted the previous year. In other words, years with high elephant numbers had high culling quotas set the next year (Whyte 2001). In some ways, management's response was itself a density-dependent response. It is thus not surprising that we observed negative density-dependent population growth during the period when the elephant population was maintained at a target population size through regular culling (Appendix 1 Figure 1-A1; Table 2-A1). However, this 'density-dependent' population growth during the culling periods was not in response to resource constraints and once the population was released from culling the population growth rate switched to an exponential pattern (Figure 2). This is similar to observations elsewhere in South Africa (Slotow et al. 2006).

Exponential growth models describe the growth of populations in the absence of density-dependent growth constraints. As the elephant population growth was well described by an exponential growth model, it suggests that the KNP elephant population has not yet reached the point where resource constraints curtail the overall population growth in the park. That is, the population has not yet reached the total carrying capacity of the park (Van Dyken \& Zhang 2019). For large vertebrates such as elephants, the effect of density on growth rates might only play out and become notable when population abundances have reached levels close to or above the carrying capacity (Fowler 1981; Sibly et al. 2005). Furthermore, in a large protected area, the total carrying capacity of the habitat becomes difficult to establish as it is then a function of local population growth parameters, habitat heterogeneity and the strength of dispersal (Van Dyken \& Zhang 2019). In such cases, the population dynamics and presence of localised density dependence might differ from the dynamics observed for the population as a whole.

The effect of density dependence can therefore be scaledependent. We failed to observe density-dependent growth at the scale of the entire park (i.e. the overall population growth; Figure 2 and Figure 3a), but we detected densitydependence effects on elephant growth at local scales (i.e. when growth was considered as spatially explicit across $25 \mathrm{~km}^{2}$ grid-cells). In particular, in the core zone we detected significant density-dependent growth (Figure 3d). These significant local-scale density-dependent growths were masked in the overall park-scale growth because of the spatial variation in local density-dependent growth (Figure 3b, 3c). The fact that density dependence was spatially variable suggests that the carrying capacity also varied across the landscape. Previous predictions that variations in local water and food availability, thus local carrying capacity, should influence the distribution and dynamics of elephants in the landscape are thus indirectly supported by our findings (Harris et al. 2008; Owen-Smith et al. 2006; Smit \& Ferreira 2010; Young et al. 2009a).

Furthermore, the density-dependent growth in the core zone aligns well with the expected convex shape suggested by Sibly et al. (2005). That is, density-dependent effects are only realised at high density levels where elephants are likely to experience increased intraspecific competition for space and food resources (MacFadyen et al. 2019). Elephants respond to variation in resources and thus move extensively across the KNP (Cook et al. 2015). Elephants choosing favoured habitats in the core zone could therefore result in increased local intraspecific competition for space/territory (i.e. between elephant herds), which will limit the number of groups that can be present in an area (MacFadyen et al. 2019). This is known to occur when one herd dominates over another (Wittemyer \& Getz 2007; Wittemyer et al. 2007), thereby displacing subordinate herds to suboptimal habitats. Such social dynamics could also accelerate herds' response to leave an area before resource conditions deteriorate to the point where a heuristic learning 'good-stay, bad-disperse' dispersal strategy is employed (Hui et al. 2012). This might explain elephant numbers rapidly increasing in the peripheral and semi-peripheral zones at roughly the same time $(2008 / 2009)$ that elephant growth in the core zone slowed down. We speculate that the peripheral and semi-peripheral zones in our study represent suboptimal habitats, as those areas had lower dry-season herd occurrences over the long term. We did not directly evaluate habitat suitability for elephants in the different density areas, as performed in previous studies (Harris et al. 2008; Young et al. 2009a). The population distribution that results from these responses is a less clumped and more homogenised pattern as elephant densities increase (MacFadyen et al. 2019; Young et al. 2009a).

How elephant herds with calves distribute in the landscape may also be explained by the aforementioned social dynamics and the distribution of resources. We observed that per-herd recruitment rates (the ratio of new calves to other herd members) were highest in the core zone (Figure 4b; Wilcoxon Rank Sum Test Table 3-A1). We expect that herds prefer to keep young calves in areas with good quality habitat, that is, close to water sources and lush vegetation, as noted elsewhere in the region (Harris et al. 2008). Yet, recruitment in peripheral and semi-peripheral zones had an upward trend (MannKendall tests: Table 4-A1). Recruitment patterns that initially differed in the core and peripheral zones, thus began to converge around 2012 (Figure $4 \mathrm{~b}$ ). This most likely reflects 
how herd groups with calves moved into suboptimal habitat as intraspecific competition for resources and space intensified (MacFadyen et al. 2019). Recruitment rates also fluctuated over time, a pattern expected given the association of first year survival with environmental conditions, for example, rainfall (Trimble et al.2009). Indeed, Robson (2015) found this to be true as variation in the proportion of elephants less than 1 year old was related to changes in vegetation productivity (NDVI), which itself was driven by rainfall in the KNP. For example, the recruitment rates increased sharply after 2000, which was also a year of exceptional rainfall in the park (MacFadyen et al. 2018) (Figure $4 b$ ). Years with high rainfall might also have an effect on recruitment in following years and future work could investigate the dynamic relationship between recruitment and rainfall.

The spatial pattern of herds with calves raises the question of how fecundity and young calf survival respond to resource constraints in areas with suboptimal habitat. Owen-Smith et al. (2006) suggested that variation in resource availability can put pressure on herds in areas where resources are more limiting. This can lead to reduced population growth through elevated mortality or hampered recruitment rates. African elephants may respond to resource constraints by reducing birth rates (Trimble et al. 2009). However, we observed that over time the proportion of calves in herds increased in semi-peripheral and peripheral zones. This suggests that conditions and resource availability in lower quality landscapes have yet to hamper fecundity and calf survival, as was predicted by Trimble et al. (2009). Purdon and Van Aarde (2017) have suggested that artificial water holes could have influenced the movements of elephants in the park and possibly reduced the effect that natural resource variation had on the elephant distribution. The effects of water holes on the population dynamics of elephants should thus be investigated in future studies.

An alternative theory is that increasing density does not reduce the survival of calves until only after they are weaned (Young \& Van Aarde 2010) at 3-4 years of age (Lee \& Moss 1986). If this is the case, calves may be most vulnerable to resource constraints shortly after weaning (Young \& Van Aarde 2010). Comparative results between several populations elsewhere in Africa highlighted that with increased daily walking distances and higher density, mortality of weaned calves does increase (Young \& Van Aarde 2010). Our census dataset did not report weaned calf mortalities, so we could not test this prediction.

In addition to the age-specific fecundity and survival data, we acknowledge the limitations of the census data as winter snapshots of elephant distributions and densities. These annual surveys (Whyte 2001) do not account for how elephants may move around throughout the year in response to seasonal changes of resources, an aspect well recorded using collared animals in the KNP (Loarie, Van Aarde \& Pimm 2009) and elsewhere (Cook et al. 2015; Roever, Van
Aarde \& Leggett 2012). All results reflect a dry-season snapshot of elephant distribution and abundance patterns. However, these dry-season months are expected to limit water availability and foraging range so it may also reflect to some degree territorial distributions (Codron et al. 2006; MacFadyen et al. 2019; Thomas et al. 2008). We report our findings as the long-term changes in dry-season elephant distributions and offer insights into how elephants are responding to changing conditions over time, as illustrated in previous studies using the same dataset (e.g. MacFadyen et al. 2019; Young et al. 2009a, 2009b).

As restoring resource gradients are expected to have parkwide effects on elephant responses (Venter et al. 2008), thus a key management approach is to focus on approaches that induce spatial variations in resources that affect how elephants use landscapes at scales within the core, semiperipheral and peripheral zones. These include, restoring food, water and comfort (e.g. shade) resource gradients (Owen-Smith et al. 2006; Purdon \& Van Aarde 2017), as well as safety or danger gradients (Douglas-Hamilton, Krink \& Vollrath 2005; Goldenberg, Douglas-Hamilton \& Wittemyer 2018; Ihwagi et al. 2018). As discussed in Carruthers (1995), a key element of how intensely elephants use a landscape also includes human disturbance as predicted from the theories such as 'landscape of fear' (Cromsigt et al. 2013). Adding to this, incorporating movement and migration patterns may help further elucidate the role of local versus regional habitat constraints on the spatial distribution and recruitment dynamics of the elephant herds in the KNP.

\section{Conclusion}

Although density dependence in elephant population growth was realised in the core zone, it coincided with the increase of elephants in the peripheral zones. This pattern could lead to a situation where elephants are more homogeneously distributed throughout the park, as also mentioned in previous studies (e.g. MacFadyen et al. 2019). A homogenised distribution of elephants in response to density-dependent factors is in direct contrast with a conservation paradigm that promotes landscape heterogeneity as an important regulator of biodiversity maintenance (Katayama et al. 2014). Our results, however, only present the population dynamics up to 2012 and could be extended to include recent census data (conducted at a biennial pace, 2015, 2017 and 2019).

Our analyses of annual census data highlighted that exponential population growth typifies elephants in the KNP at a park-wide scale after authorities stopped culling up to 2012. Per capita recruitment rate of calves less than 1 year old into the population varied over the study period but was higher in the core areas. At the park-wide scale, the expected pattern of negative density-dependent growth did not occur. We, however, detected significant negative densitydependence in elephant population growth in the core zone. The mechanism of this density dependence can be demographic responses of fecundity and survival rates and/or movements 
of elephants to the local density. The spatially varied growth patterns and the apparent change in density trends after 2008 , suggest a more pronounced future density-dependent response by elephants to local resource constraints. Such responses reflect a gradual spread of elephants into less optimal habitats during the dry season and are likely to have consequences for other species in the park.

\section{Acknowledgements Competing interests}

The authors declare that they have no financial or personal relationships that may have inappropriately influenced them in writing this article.

\section{Authors' contributions}

A.S.L., S.M. and C.H. developed the ideas, A.S.L. ran analyses and wrote the article under the guidance of C.H., S.M. and S.F.A.S.L., S.M. and C.H. and S.F. helped improve the final manuscript.

\section{Ethical considerations}

This article followed all ethical standards for research without direct contact with human or animal subjects.

\section{Funding information}

We are grateful for the financial support received from the following sources: Department of Mathematical Sciences Bursary (Stellenbosch University); NRF Grant holder-linked Bursary (NRF 89967).

\section{Data availability}

The authors confirm that the data supporting the findings of this study are available within the article.

\section{Disclaimer}

The views and opinions expressed in this article are those of the authors and do not necessarily reflect the official policy or position of any affiliated agency of the authors.

\section{References}

Boult, V.L., Sibly, R.M., Quaife, T., Fishlock, V., Moss, C. \& Lee, P.C., 2019, 'Modelling large herbivore movement decisions: Beyond food availability as a predictor of ranging patterns', African Journal of Ecology 57(1), 10-19. https://doi.org/ 10.1111/aje. 12553

Carruthers, J., 1995, The Kruger National Park: A social and political history, University of Natal Press, Pietermaritzburg.

Chamaillé-Jammes, S., Valeix, M. \& Fritz, H., 2007, 'Managing heterogeneity in elephant distribution: Interactions between elephant population density and surface-water availability', Journal of Applied Ecology 44(3), 625-633. https://doi. org/10.1111/j.1365-2664.2007.01300.x

Chase, M.J., Schlossberg, S., Griffin, C.R., Bouché, P.J., Djene, S.W., Elkan, P.W., et al., 2016, 'Continent-wide survey reveals massive decline in African savannah elephants', PeerJ4, e2354. https://doi.org/10.7717/peerj.2354

Codron, J., Lee-Thorp, J.A., Sponheimer, M., Codron, D., Grant, R.C., De Ruiter, D.J., 2006, 'Elephant (Loxodonta africana) diets in Kruger National Park, South Africa: Spatial and landscape differences', Journal of Mammalogy 87(1), 27-34. https:// doi.org/10.1644/05-MAMM-A-017R1.1

Cook, R.M., Henley, M.D. \& Parrini, F., 2015, 'Elephant movement patterns in relation to human inhabitants in and around the Great Limpopo Transfrontier Park', Koedoe 57(1), 1-7. https://doi.org/10.4102/koedoe.v57i1.1298
Cromsigt, J.P., Kuijper, D.P., Adam, M., Beschta, R.L., Churski, M., Eycott, A. et al., 2013, 'Hunting for fear: Innovating management of human-wildlife conflicts', Journal of Applied Ecology 50(3), 544-549. https://doi.org/10.1111/1365-2664.12076

Dennis, B. \& Taper, M.L., 1994, 'Density dependence in time series observations of natural populations: Estimation and testing', Ecological Monographs 64(2), 205-224. https://doi.org/10.2307/2937041

Douglas-Hamilton, I., Krink, T. \& Vollrath, F., 2005, 'Movements and corridors of African elephants in relation to protected areas', Naturwissenschaften 92(4), 158-163. https://doi.org/10.1007/s00114-004-0606-9

Eberhardt, L.L., 2002, 'A paradigm for population analysis of long-lived vertebrates', Ecology 83(10), 2841-2854. https://doi.org/10.1890/0012-9658(2002)083[2841:AP FPAO]2.0.CO;2

Eckhardt, H.C., Van Wilgen, B.W. \& Biggs, H.C., 2000, 'Trends in woody vegetation cover in the Kruger National Park, South Africa, between 1940 and 1998', African Journal of Ecology 38(2), 108-115. https://doi.org/10.1046/j.1365-2028.2000. 00217.x

Ferreira, S.M., Greaver, C. \& Simms, C., 2017, 'Elephant population growth in Kruger National Park, South Africa, under a landscape management approach', Koedoe National Park, South Africa, under a landscape managem
59(1), 1-6. https://doi.org/10.4102/koedoe.v59i1.1427

Fowler, C.W., 1981, 'Density dependence as related to life history strategy', Ecology 62, 602-610. https://doi.org/10.2307/1937727

Gertenbach, W.P.D., 1983, 'Landscapes of the Kruger National Park', Koedoe 26(1), 9-121. https://doi.org/10.4102/koedoe.v26i1.591

Goldenberg, S.Z., Douglas-Hamilton, I. \& Wittemyer, G., 2018, 'Inter-generational change in African elephant range use is associated with poaching risk, primary productivity and adult mortality', Proceedings of the Royal Society B: Biological Sciences 285(1879), 20180286. https://doi.org/10.1098/rspb.2018.0286

Gough, K.F. \& Kerley, G.I., 2006, 'Demography and population dynamics in the elephants Loxodonta africana of Addo Elephant National Park, South Africa: Is there evidence of density-dependent regulation?', Oryx 40(4), 434-441. https:// doi.org/10.1017/S0030605306001189

Harris, G.M., Russell, G.J., Van Aarde, R.I. \& Pimm, S.L., 2008, 'Rules of habitat use by elephants Loxodonta africana in southern Africa: Insights for regional management', Oryx 42(1), 66-75. https://doi.org/10.1017/\$0030605308000483

Hijmans, R.J., 2020, Raster: Geographic data analysis and modelling, version 3.3-13, computer software, viewed 27 February 2021, from https://CRAN.R-project.org/ package=raster.

Hixon, M.A. \& Johnson, D.W., 2009, 'Density dependence and independence', Encyclopedia of Life Sciences (ELS), John Wiley \& Sons, Chichester. https://doi. org/10.1002/9780470015902.a0021219

Hui, C., Roura-Pascual, N., Brotons, L., Robinson, R.A. \& Evans, K.L., 2012, 'Flexible dispersal strategies in native and non-native ranges: Environmental quality and the 'good-stay, bad-disperse' rule', Ecography 35(11), 1024-1032. https://doi. org/10.1111/j.1600-0587.2012.07697.x

Ihwagi, F.W., Thouless, C., Wang, T., Skidmore, A.K., Omondi, P. \& Douglas-Hamilton, I., 2018, 'Night-day speed ratio of elephants as indicator of poaching levels', Ecological Indicators 84, 38-44. https://doi.org/10.1016/j.ecolind.2017.08.039

Katayama, N., Amano, T., Naoe, S., Yamakita, T., Komatsu, I., Takagawa, S.I. et al., 2014, 'Landscape heterogeneity-biodiversity relationship: Effect of range size', PLoS One 9(3), e93359. https://doi.org/10.1371/journal.pone.0093359

Kerley, G., Boshoff, A. \& Knight, M.H., 2002, 'The Greater Addo National Park, South Africa: Biodiversity conservation as the basis for a healthy ecosystem and human development opportunities', in D.J. Rapport, B.L. Lasley, D.E. Rolston, N.O. Nielsen, C.O. Qualset \& A.B Damania (eds.), Managing for healthy ecosystems, p. 16, CRC Press, Boca Raton, FL.

Kinahan, A.A., Pimm, S.L. \& Van Aarde, R.J., 2007, 'Ambient temperature as a determinant of landscape use in the savanna elephant, Loxodonta africana', Journal of Thermal Biology 32(1), 47-58. https://doi.org/10.1016/j.jtherbio.2006. 09.002

Lee, P.C. \& Moss, C.J., 1986, 'Early maternal investment in male and female African elephant calves', Behavioral Ecology and Sociobiology 18(5), 353-361. https://doi. org/10.1007/BF00299666

Loarie, S.R., Van Aarde, R.J. \& Pimm, S.L., 2009, 'Elephant seasonal vegetation preferences across dry and wet savannas', Biological Conservation 142(12), preferences across dry and wet savannas', Biological
3099-3107. https://doi.org/10.1016/j.biocon.2009.08.021

MacFadyen, S., Hui, C., Verburg, P.H. \& Van Teeffelen, A.J.A., 2019, 'Spatiotemporal distribution dynamics of elephants in response to density, rainfall, rivers and fire in Kruger National Park, South Africa', Diversity and Distributions 25(6), 880-894. https://doi.org/10.1111/ddi.12907

MacFadyen S., Zambatis N., Van Teeffelen A.J.A. \& Hui, C., 2018, 'Long-term rainfall regression surfaces for the Kruger National Park, South Africa: A spatio-temporal review of patterns from 1981 to 2015', International Journal of Climatology 38(5), 2506-2519. https://doi.org/10.1002/joc.5394

Owen-Smith, N., Kerley, G.I.H., Page, B., Slotow, R. \& Van Aarde, R.J., 2006, 'A scientific perspective on the management of elephants in the Kruger National Park and elsewhere', South African Journal of Science 102(9-10), 389-394.

Pienaar, D., Biggs, H., Deacon, A., Gertenbach, W., Joubert, S., Nel, F. et al., 1997 $A$ revised water-distribution policy for biodiversity maintenance in the Kruger National Park, Internal Report South African National Parks, Skukuza.

Pretorius, Y., Garaï, M.E. \& Bates, L.A., 2019, 'The status of African elephant Loxodonto africana populations in South Africa', Oryx 53(4), 757-763. https://doi.org/ 10.1017/S0030605317001454

Purdon, A. \& Van Aarde, R.J., 2017, 'Water provisioning in Kruger National Park alters elephant spatial utilisation patterns', Journal of Arid Environments 141, 45-51. https://doi.org/10.1016/j.jaridenv.2017.01.014 
R Core Team, 2019, R: A language and environment for statistical computing, computer software, viewed 14 August 2019, from https://www.r-project.org/.

Robson, A.S., 2015, 'Demographic responses to changes in conservation management: A case study on elephants in the Kruger National Park', MSc-thesis, University of Pretoria, Pretoria.

Robson, A.S., Trimble, M.J., Purdon, A., Young-Overton, K.D., Pimm, S.L. \& Van Aarde, R.J., 2017, 'Savanna elephant numbers are only a quarter of their expected values', PLoS One 12(4), e0175942. https://doi.org/10.1371/journal.pone.0175942

Robson, A.S. \& Van Aarde, R.J., 2018, 'Changes in elephant conservation management promote density-dependent habitat selection in the Kruger National Park', Animal Conservation 21(4), 302-312. https://doi.org/10.1111/acv.12393

Roever, C.L., Van Aarde, R.J. \& Leggett, K., 2012, 'Functional responses in the habitat selection of a generalist mega-herbivore, the African savannah elephant', Ecography 35(11), 972-982. https://doi.org/10.1111/j.1600-0587.2012.07359.x

Selier, S.A.J., Henley, M., Pretorius, Y. \& Garai, M., 2016, 'A conservation assessment of Loxodonta africana', in M.F. Child, L. Roxburgh, E. Do Linh San, D. Raimondo, J. Selier \& HT. Davies-Mostert (eds.), The red list of mammals of South Africa, Swaziland and Lesotho, South African National Biodiversity Institute and Endangered Wildlife Trust, South Africa.

Sibly, R.M., Barker, D., Denham, M.C., Hone, J. \& Pagel, M., 2005, 'On the regulation of populations of mammals, birds, fish, and insects', Science 309(5734), 607-610. https://doi.org/10.1126/science.1110760

Slotow, R., Page, B.R., Mackey, R.L. \& Duffy, K.J., 2006, 'Modelling elephant population growth in small, fenced, South African reserves', South African Journal of Wildlife Research 36(1), 33-43.

Smit, I.P. \& Ferreira, S.M., 2010, 'Management intervention affects river-bound spatia dynamics of elephants', Biological Conservation 143(9), 2172-2181. https://doi. org/10.1016/j.biocon.2010.06.001

Thomas, B., Holland, J.D., Minot, E.O., 2008, 'Elephant (Loxodonta africana) home ranges in Sabisand reserve and Kruger National Park: A five-year satellite tracking study', PLoS One3(12), e3902. https://doi.org/10.1371/journal.pone.0003902

Trimble, M.J., Ferreira, S.M. \& Van Aarde, R.J., 2009, 'Drivers of megaherbivore demographic fluctuations: Inference from elephants', Journal of Zoology 279(1) 18-26. https://doi.org/10.1111/j.1469-7998.2009.00560.x

Trollope, W.S.W., Trollope, L.A., Biggs, H.C., Pienaar, D. \& Potgieter, A.L.F., 1998, 'Longterm changes in the woody vegetation of the Kruger National Park, with special reference to the effects of elephants and fire', Koedoe 41(2), 103-112. https://doi. org/10.4102/koedoe.v41i2.255

Tsoularis, A.N. \& Wallace, J., 2002, 'Analysis of logistic growth models', Mathematical Biosciences179(1), 21-55. https://doi.org/10.1016/s0025-5564 (02)00096-2

Valeix, M., Fritz, H., Sabatier, R., Murindagomo, F., Cumming, D. \& Duncan, P., 2011, 'Elephant-induced structural changes in the vegetation and habitat selection by large herbivores in an African savanna', Biological Conservation 144(2), 902-912. https://doi.org/10.1016/j.biocon.2010.10.029

Van Aarde, R.J., Jackson, T.P. \& Ferreira, S.M., 2006, 'Conservation science and elephant management in southern Africa: Elephant conservation', South African Journal of Science 102(9-10), 385-388.
Van Aarde, R.J., Whyte, I. \& Pimm, S., 1999, 'Culling and the dynamics of the Kruger National Park African elephant population', Animal Conservation 2(4), 287-294. https://doi.org/10.1111/j.1469-1795.1999.tb00075.x

Van Dyken, J.D. \& Zhang, B., 2019, 'Carrying capacity of a spatially-structured population: Disentangling the effects of dispersal, growth parameters, habitat heterogeneity and habitat clustering', Journal of Theoretical Biology 460, 115-124. https://doi.org/10.1016/j.jtbi.2018.09.015

Van Wyk, P. \& Fairall, N., 1969, 'The influence of the African elephant on the vegetation of the Kruger National Park', Koedoe 12(1), a747. https://doi.org/10.4102/ koedoe.v12i1.747

Venter, F.J., Naiman, R.J., Biggs, H.C. \& Pienaar D.J., 2008, 'The evolution of conservation management philosophy: Science, environmental change and social adjustments in Kruger National Park', Ecosystems 11, 173-192. https://doi. org/10.1007/s10021-007-9116-x

Verhulst, P.-F., 1845, 'Recherchesmathématiques sur la loid'accroissement de la population [Mathematical researches into the law of population growth increase]', Nouveaux mémoires de l'Académieroyale des sciences et belles-lettres de Bruxelles $18,14-50$.

Whyte, I.J., 2001, 'The conservation management of the Kruger National Park elephant population', PhD thesis, University of Pretoria, Pretoria.

Whyte, I.J., Biggs, H.C., Gaylard, A. \& Braack, L.E.O., 1999, 'A new policy for the management of the Kruger National Park's elephant population', Koedoe 42(1), 111-132. https://doi.org/10.4102/koedoe.v42i1.228

Wickham, H., 2016, ggplot2: Elegant graphics for data analysis, Springer-Verlag, New York, NY.

Wittemyer, G. \& Getz, W.M., 2007, 'Hierarchical dominance structure and social organization in African elephants, Loxodontaafricana', Animal Behaviour 73(4), 671-681. https://doi.org/10.1016/j.anbehav.2006.10.008

Wittemyer, G., Getz, W.M., Vollrath, F. \& Douglas-Hamilton, I., 2007, 'Social dominance, seasonal movements, and spatial segregation in African elephants: a contribution to conservation behavior', Behavioral Ecology and Sociobiology 61(12), 1919-1931. https://doi.org/10.1007/s00265-007-0432-0

Wittemyer, G., Keating, L.M., Vollrath, F. \& Douglas-Hamilton, I., 2017, 'Graph theory illustrates spatial and temporal features that structure elephant rest locations and reflect risk perception', Ecography 40(5), 598-605. https://doi.org/10.1111/ ecog.02379

Young, K.D., Ferreira, S.M. \& Van Aarde, R.J., 2009a, 'The influence of increasing population size and vegetation productivity on elephant distribution in the Kruger National Park', Austral Ecology 34(3), 329-342. https://doi.org/10.1111/j.1442 9993.2009.01934

Young, K.D., Ferreira, S.M. \& Van Aarde, R.J., 2009b, 'Elephant spatial use in wet and dry savannas of southern Africa', Journal of Zoology 278(3), 189-205. https://doi. org/10.1111/j.1469-7998.2009.00568.x

Young, K.D. \& Van Aarde, R.J., 2010, 'Density as an explanatory variable of movements and calf recruitment in savannah elephants across southern Africa', Journal of Animal Ecology 79(3), 662-673. https://doi.org/10.1111/j.13652656.2010.01667.x 


\section{Appendix 1}

TABLE 1-A1: Exponential growth model parameter estimates and model statistics

(Eqn 2).

\begin{tabular}{lcc}
\hline Model parameters & \multicolumn{2}{c}{ Parameter estimates } \\
\cline { 2 - 3 } & Cull Model & No-cull Model \\
\hline Per-capita annual growth rate & $0.006^{* *}$ & $0.041^{* * *}$ \\
$r$ & 0.002 & 0.002 \\
Initial population density & $0.368^{* *}$ & $0.407^{* *}$ \\
$d_{0}$ & $(4.542)$ & $(4.894)$ \\
Observations & 11 & 17 \\
$R^{2}$ & 0.406 & 0.949 \\
Adjusted $R^{2}$ & 0.340 & 0.945 \\
Residual standard error & 0.024 & 0.049 \\
$d f$ & 9 & 15 \\
F-Statistic & $6.158^{* *}$ & $278.423^{* * *}$ \\
$d f$ & $1 ; 9$ & $1 ; 15$ \\
\hline
\end{tabular}

$d f$, degree of freedom.

$*, p<0.1 ; * *, p<0.05 ; * * *, p<0.01$.

TABLE 2-A1: Parameter estimates of stochastic Ricker model fitted to the time series of elephant population size, as part of test for negative density-dependent growth. Time period Model parameters Parameter estimates: Density classes (elephants per square $\mathrm{km}$ )

\begin{tabular}{|c|c|c|c|c|c|}
\hline & & & & & \\
\hline & & Overall & Peripheral $(0.0-0.5)$ & Semi-peripheral (0.5-1.0) & core $(>1)$ \\
\hline \multirow{6}{*}{$\begin{array}{l}\text { Culling period } \\
\text { (1985-1995) }\end{array}$} & $a$ & 1.20 & 0.90 & 1.44 & 1.26 \\
\hline & $95 \%$ bootsrap $\mathrm{Cl}$ & $0.347-1.607$ & $0.246-1.813$ & $0.909-2.189$ & 0.833 \\
\hline & $b$ & $-1.2 \mathrm{E}-4 \dagger$ & $-4.0 \mathrm{E}-4 \dagger$ & $-4.4 \mathrm{E}-4 \dagger$ & $-7.2 \mathrm{E}-4 \dagger$ \\
\hline & $95 \%$ bootsrap $\mathrm{Cl}$ & $-2.2 \mathrm{E}-04--5.0 \mathrm{E}-05$ & $-8.2 \mathrm{E}-04--1.4 \mathrm{E}-04$ & $-6.8 \mathrm{E}-04--2.8 \mathrm{E}-04$ & $-1.1 \mathrm{E}-03$ \\
\hline & Observations & 11 & 11 & 11 & 11 \\
\hline & Bootstrap samples & 2000 & 2000 & 2000 & 2000 \\
\hline \multirow{6}{*}{$\begin{array}{l}\text { Post-culling } \\
\text { period } \\
\text { (1996-2012) }\end{array}$} & $a$ & 0.02 & -0.071 & 0.19 & 0.334 \\
\hline & $95 \%$ bootsrap $\mathrm{Cl}$ & $-0.163-0.179$ & $-0.669-0.670$ & $-0.077-0.367$ & 0.120 \\
\hline & $b$ & $1.8 \mathrm{E}-06$ & $3.4 \mathrm{E}-05$ & $-3.3 E-05$ & $-1.2 \mathrm{E}-4 \dagger$ \\
\hline & $95 \%$ bootsrap $\mathrm{Cl}$ & $-1.2 \mathrm{E}-05-1.9 \mathrm{E}-05$ & $-1.9 \mathrm{E}-04-2.1 \mathrm{E}-04$ & $-6.8 \mathrm{E}-05-2.5 \mathrm{E}-05$ & $-2.3 \mathrm{E}-04$ \\
\hline & Observations & 17 & 17 & 17 & 17 \\
\hline & Bootstrap samples & 2000 & 2000 & 2000 & 2000 \\
\hline
\end{tabular}

Note: $a$ and $b$ are growth rate parameters describing the respective density-independent and density-dependent components of growth. Results shown for models fitted to overall growth, as well as in the zones divided according to long-term average density (peripheral, semi-peripheral and core). Models fitted for culling period (1985-1995) and the post-culling period (1996-2012) [Eqn 3]. $\mathrm{Cl}$, confidence interval.

$\dagger$, Show $b$ estimates for which $\mathrm{H}_{0}: b=0$ is rejected at $\alpha=0.05$, in favour of $\mathrm{H}_{\mathrm{a}}: b<0$.

TABLE 3-A1: Test statistics of Mann-Whitney $U$ tests for difference in recruitment rates in the three long-term density zones. $p$-values corrected for multiple comparison by Holm method.

\begin{tabular}{lcccccc}
\hline Group1 & Group2 & n1 & n2 & Statistic & $p$ & p.adj \\
\hline Peripheral & Core & 2810 & 1108 & 1388345 & $2.97 \mathrm{E}-08$ & $8.91 \mathrm{E}-08$ \\
Semi-peripheral & Core & 2984 & 1108 & 1535289.5 & 0.000182 & 0.000364 \\
Core & Semi-peripheral & 2810 & 2984 & 4032359 & 0.005 & $* * *$ \\
\hline
\end{tabular}

Note: Pairwise Wilcoxon rank sum test. $p$-values adjusted for multiple comparison with Holm method. Alternative Hypothesis: group 2 shifted to the right of group 1.

p.adj, adjusted $p$-values; p.adj.signif., significance level of adjusted $p$-values.

$*, p<0.1 ; * *, p<0.05 ; * * *, p<0.01$.

TABLE 4-A1: Test statistics of Mann-Kendall test for trend in the average elephant recruitment rates in areas belonging to different zones.

\begin{tabular}{lccccc}
\hline Zone & \multicolumn{5}{c}{ Statistics } \\
\cline { 2 - 6 } & Tau & two-sided $\boldsymbol{p}$ & $\begin{array}{c}\text { Kendall } \\
\text { score (S) }\end{array}$ & Denominator & $\begin{array}{c}\text { Variance } \\
\text { of S }\end{array}$ \\
\hline Peripheral & 0.28571 & 0.03452 & 108 & 378.00003 & 2562 \\
Semi-peripheral & 0.32275 & 0.01682 & 122 & 378.00003 & 2562 \\
Core & 0.14814 & 0.27721 & 56 & 378.00003 & 2562 \\
\hline
\end{tabular}

Note: Mann-Kendall tests for trend in the recruitment rates of the three density groups. 


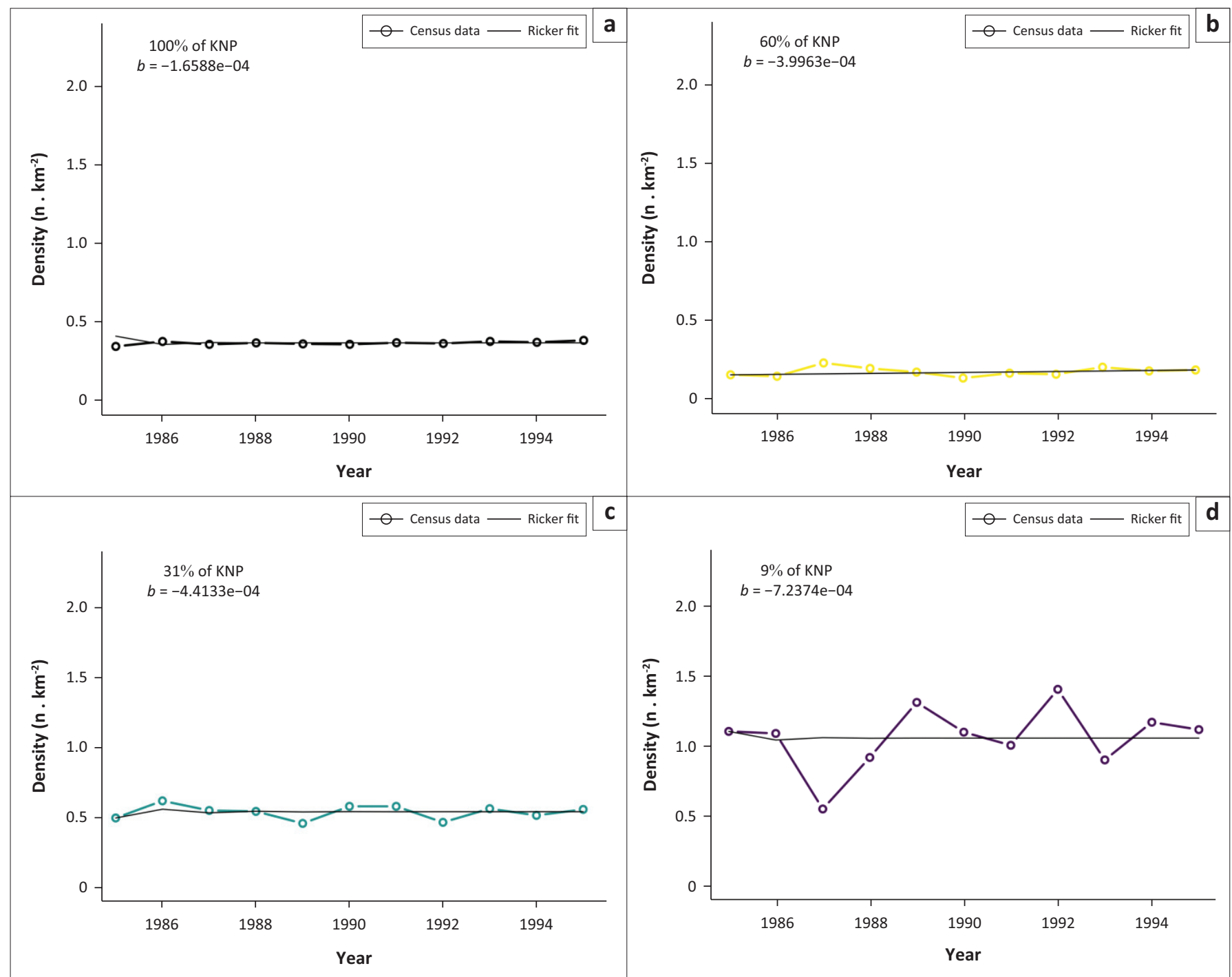

Note: Please see the article, Louw, A.S., MacFadyen, S., Ferreira, S. \& Hui, C., 2021, 'Elephant population responses to increased density in Kruger National Park', Koedoe 63(1), a1660. https://doi. org/10.4102/koedoe.v63i1.1660, for more information.

KNP, Kruger National Park.

FIGURE 1-A1: (a) Overall, (b) peripheral zone, (c) semi-peripheral zone and (d) core Zone. Deterministic component of Ricker growth models (Eqn 3) fitted to time-series of elephant population in Kruger National Park during the period of regular culling (1985-2012) Model parameter estimates in Appendix 1 (Table 2-A1). Models shown for overall population, and separately for three zones in the park having low medium or high long-term average elephant density (denoted as 'peripheral', 'semi-peripheral' and 'core' zones for elephants). Test for negative density-dependent growth reported significant for all the zones, and the population overall. 


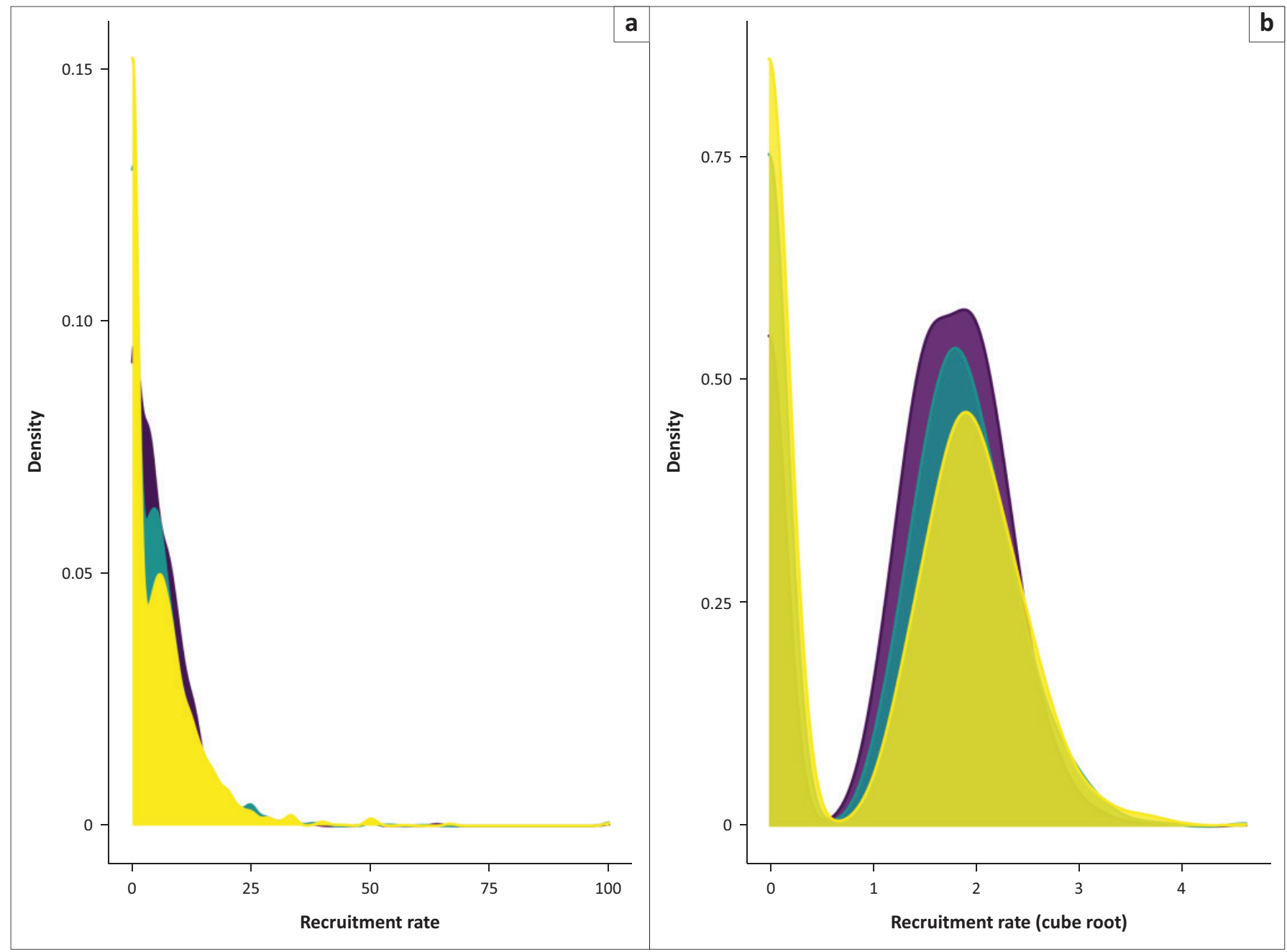

KNP, Kruger National Park.

FIGURE 2-A1: Distribution plots of Recruitment rate observations. (a) Shows recruitment rates are skewed and (b) shows a cube root transformation of the recruitment rates, to reduce skewness. 